\title{
A mussel watch in the Ria Formosa lagoon
}

\section{Programa de vigilancia de mejillones en la Ría Formosa}

\author{
M.E. Morgado \\ M.J. Bebianno* \\ CIMA \\ Laboratório de Ecotoxicologia e Química Ambiental \\ Universidade do Algarve \\ Campus de Gambelas \\ 8000-810 Faro, Portugal \\ * E-mail: mbebian@ualg.pt \\ Recibido en junio de 2003; aceptado en marzo de 2004
}

\begin{abstract}
The present work analyzes the concentrations of various metals (Ag, $\mathrm{Cd}, \mathrm{Cr}, \mathrm{Cu}, \mathrm{Ni}, \mathrm{Pb}$ and $\mathrm{Zn}$ ) in the edible part of the mussel Mytilus galloprovincialis from the Ria Formosa lagoon (Portugal). Mussels of a similar size (5-7 cm) were collected. The results indicate that the dispersion and accumulation of metals in mussels is influenced essentially by the sources of pollution and the bioavailability of the metal. The highest concentrations of Ag, $\mathrm{Cu}$ and Ni occurred in the mussels from sites 1, 6 and 7, which are mainly related to inputs from urban discharges. The highest concentrations of Cr were found in the mussels from sites 2 and 5 , located near urban discharges and metallic structures. The highest concentrations of Pb were recorded in the mussels from site 9 , associated with fuel from boats and diffuse inputs of this metal. The mussels at sites 3, 4 and 9 presented the highest concentrations of Zn and Cd, probably caused by physical and chemical processes that occur in the boundary between the lagoon and the ocean. The concentrations of $\mathrm{Ag}$ and $\mathrm{Ni}$ in the mussels of Ria Formosa are relatively low when compared to other geographical locations. The concentrations of $\mathrm{Cd}, \mathrm{Cr}, \mathrm{Cu}$ and $\mathrm{Pb}$ accumulated in the mussels reveal low contamination. As for the concentration of $\mathrm{Zn}$, the values in the Ria Formosa mussels are higher in the eastern part of the lagoon than in the western part, revealing signs of contamination by this metal.
\end{abstract}

Key words: Mussel Watch, metals, Ria Formosa.

\section{Resumen}

Se analizaron las concentraciones de varios metales (Ag, Cd, Cr, $\mathrm{Cu}, \mathrm{Ni}, \mathrm{Pb}$ y $\mathrm{Zn}$ ) en la parte comestible del mejillón Mytilus galloprovincialis de la Ría Formosa (Portugal), para lo cual se recolectaron ejemplares de tamaño similar (5-7 cm). Los resultados indican que la dispersión y acumulación de metales en los mejillones es influenciada esencialmente por las fuentes de contaminación y la biodisponibilidad del metal. Las concentraciones más elevadas de Ag, Cu y Ni se registraron en los mejillones de las estaciones 1, 6 y 7, relacionadas principalmente con el vertido de descargas urbanas. Las concentraciones mayores de Cr se observaron en los mejillones de las estaciones 2 y 5, localizadas cerca de descargas urbanas y estructuras metálicas. Las concentraciones más altas de $\mathrm{Pb}$ se presentaron en los mejillones de la estación 9, lo cual se asocia con el combustible de barcos y aportes difusos de este metal. Los mejillones de las estaciones 3, 4 y 9 tuvieron las concentraciones más elevadas de Zn y Cd, probablemente como consecuencia de los procesos físicos y químicos que se presentan en el límite entre la laguna y el océano. Las concentraciones de Ag y Ni en los mejillones de la Ría Formosa son relativamente bajos en comparación con otros sitios geográficos. Las concentraciones de $\mathrm{Cd}$, $\mathrm{Cr}$, $\mathrm{Cu}$ y $\mathrm{Pb}$ acumuladas en los mejillones muestran poca contaminación. En cuanto a la concentración de Zn, los valores para los mejillones de la Ría Formosa son mayores en la parte oriental de la laguna que en la parte occidental, lo que indica contaminación por este metal.

Palabras clave: programa de vigilancia de mejillones, metales, Ría Formosa.

\section{Introduction}

The concentration of trace metals in the environment can be measured through the water, sediments or biota. Biota integrates in space and time the metal concentration in the environment and this concentration is a measure of the

\section{Introducción}

La concentración de metales traza en el medio puede ser medida en el agua, los sedimentos o la biota. La biota integra, en el espacio y el tiempo, la concentración de metales en el ambiente y ésta constituye una medida de su biodisponibilidad, 
bioavailability of the metal. This is because many organisms are able to concentrate metals in much higher concentrations than those present in the marine environment (Rainbow, 1996).

Marine organisms used to quantify metal bioavailability are designated as bioindicators, sentinel organisms or biomonitors. They should comply with several criteria, such as being sedentary and representative of a wide area, having a long life span, being abundant, easy to identify and available for sampling all year round, providing sufficient tissue for analysis, being resistant to stress caused by handling and transportation, and tolerating wide variations of physical and chemical parameters. Many species selected as biomonitors do not comply with all of these criteria, but they show a high accumulation potential for the metals under study (Rainbow and Phillips, 1993; Rainbow, 1995; Boening, 1999). The use of species of the genus Mytilus as for this purposes is very frequent since they are cosmopolitan, tolerate eutrophic coastal waters and great variations of salinity and temperature, and are efficient accumulators of several trace metals (Kennish, 1992; Rainbow, 1995). In the past decades, intensive monitoring programs for assessing contamination levels in marine ecosystems have been made using mussels as sentinel organisms. Among these, the Mussel Watch developed by Goldberg et al. (1978) is considered of extreme importance (Lauenstein et al., 1990).

The monitoring of trace metals in the Ria Formosa lagoon is also of extreme importance since this system is highly productive and dynamic, and supports innumerable organisms, for which it has been designated a Natural Park, a special protection zone and an important bird area. Moreover, Ria Formosa has a long mariculture tradition, especially of Ruditapes decussatus that constitutes about $90 \%$ of the Portuguese production, and has important fishery industries (Bebianno, 1995; Mudge and Bebianno, 1997; Matos et al., 1999). Also an important tourism area, Ría Formosa is under the influence of several anthropogenic wastewater sources that have contributed to the deterioration of the system's water quality. The most significant inputs of contaminants are from point sources, like urban and industrial wastewaters, and from diffuse sources, like agricultural runoffs, road runoffs, ports, marinas and aquaculture (Bebianno, 1995; Mudge and Bebianno, 1997).

The aim of this study was to monitor, using the species Mytilus galloprovincialis as bioindicator, the level of seven trace metals, namely $\mathrm{Ag}, \mathrm{Cd}, \mathrm{Cr}, \mathrm{Cu}, \mathrm{Pb}, \mathrm{Ni}$ and $\mathrm{Zn}$, in several sampling sites in the Ria Formosa lagoon, and evaluate their spatial and temporal variation in comparison to previous studies.

\section{Material and methods}

Several specimens of $M$. galloprovincialis were collected in April 2001 at a total of nine sampling sites along the Ria Formosa lagoon (fig. 1), from site 1 (Ilha de Faro) to site 9 (Tavira). At every site, about 20 individuals ranging in size from 5 to $7 \mathrm{~cm}$ were collected. In the laboratory, specimens debido a que muchos organismos tienen la capacidad de concentrar metales en concentraciones mucho mayores que las que se encuentran en el medio marino (Rainbow, 1996).

Los organismos marinos que se utilizan para cuantificar la biodisponibilidad de un metal son designados como bioindicadores, organismos centinelas o biomonitores. Éstos deberán cumplir con varios criterios, tales como ser sedentarios y representativos de un área amplia, tener una vida larga, ser abundantes y fáciles de identificar, estar disponibles para muestreo durante todo el año, proveer suficiente tejido para los análisis, ser resistentes al estrés producido por el manejo y transporte, y tolerar variaciones amplias de los parámetros fisicoquímicos. Muchas especies seleccionadas como biomonitores no cumplen con todos estos criterios, pero poseen un alto potencial de acumulación de los metales bajo estudio (Rainbow y Phillips, 1993; Rainbow, 1995; Boening, 1999). El uso de especies del género Mytilus como bioindicadores es muy frecuente, ya que son cosmopolitas, toleran aguas costeras eutróficas y grandes variaciones de salinidad y temperatura, además de ser eficientes acumuladores de varios metales traza (Kennish, 1992; Rainbow, 1995). En las últimas décadas se han realizado programas intensivos de vigilancia para evaluar los niveles de contaminación de ecosistemas marinos utilizando mejillones como organismos centinelas. Entre éstos, el programa de vigilancia de mejillones conocido como Mussel Watch desarrollado por Goldberg et al. (1978) es considerado de gran importancia (Lauenstein et al., 1990).

El estudio de metales traza en la Ría Formosa es de gran importancia ya que ésta es un sistema altamente productivo y dinámico, y mantiene innumerables organismos, por lo cual ha sido designada Parque Natural, zona de protección especial y es una importante área para múltiples especies de aves. Asimismo, la Ría Formosa tiene una larga tradición de maricultura, especialmente de Ruditapes decussatus que constituye alrededor de $90 \%$ de la producción portuguesa, además de poseer importantes industrias pesqueras (Bebianno, 1995; Mudge y Bebianno, 1997; Matos et al., 1999). Es una zona de alto valor turístico y consecuentemente se ve afectada por varias descargas antropogénicas que han contribuido al deterioro de la calidad del agua del sistema. Las contribuciones más significativas de contaminantes provienen de fuentes puntuales, como aguas residuales urbanas e industriales, y de fuentes difusas, como escurrimiento agrícola, puertos, marinas y acuicultura (Bebianno, 1995; Mudge y Bebianno, 1997).

El objetivo del presente trabajo fue determinar los niveles de siete metales traza ( $\mathrm{Ag}, \mathrm{Cd}, \mathrm{Cr}, \mathrm{Cu}, \mathrm{Pb}, \mathrm{Ni}$ y $\mathrm{Zn}$ ) en varios sitios de la Ría Formosa, usando la especie Mytilus galloprovincialis como bioindicador, y evaluar su variación espacial y temporal en comparación con estudios previos.

\section{Materiales y métodos}

En abril de 2001 se recolectaron varios especímenes de $M$. galloprovincialis de un total de nueve sitios de muestreo a lo largo de la Ría Formosa (fig. 1), de la estación 1 (Ilha de Faro) 
were depurated for a 48-h period in order to clear out the gut content. Each sample was labelled and frozen at $-20^{\circ} \mathrm{C}$ until laboratory analysis. Six mussels from each sampling site were thawed. The length, width, height, sex and maturation stage were recorded for each organism. The byssus was removed from the organisms and the total edible part placed in a Teflon vessel. A high performance microwave oven was used to dry and digest the tissue samples. For the digestion, $4 \mathrm{~mL}$ of $\mathrm{HNO}_{3}$ $69 \%$ Aristar and $1 \mathrm{~mL}$ of $\mathrm{H}_{2} \mathrm{O}_{2} 30 \%$ Sigma were added.

\section{Metal analysis}

The metals were quantified with a Perkin-Elmer Analyst 800 atomic absorption spectrophotometer; $\mathrm{Zn}$ was determined by flame and $\mathrm{Ag}, \mathrm{Cd}, \mathrm{Cr}, \mathrm{Cu}, \mathrm{Ni}$ and $\mathrm{Pb}$ by graphite furnace.

Certified reference material was used to validate the results, namely TORT-1 (defatted lobster hepatopancreas, Homarus americanus) and LUTS-1 (non-defatted lobster hepatopancreas, $H$. americanus) from the National Research Council of Canada. The recoveries of all metals, except for $\mathrm{Pb}$ and $\mathrm{Zn}$, ranged from $80 \%$ to $120 \%$. Concentrations of all elements are reported as $\mathrm{mg} \mathrm{g}^{-1}$ on a dry weight basis.

\section{Statistical analysis}

The mean concentration, standard deviation and coefficient of variation were determined for each metal at the nine sampling sites. In order to verify the differences in metal concentration between sites, a Kruskal-Wallis non-parametric test of variance was applied. The null and alternative hypotheses were: $\mathrm{H}_{0}=$ the metal concentration is the same among the stations and $\mathrm{H}_{1}=$ the metal concentration is different among the stations. The level of significance established was $5 \%$.

Statistical treatments also included a numeric classification method, cluster analysis (CA), and an ordination method, the

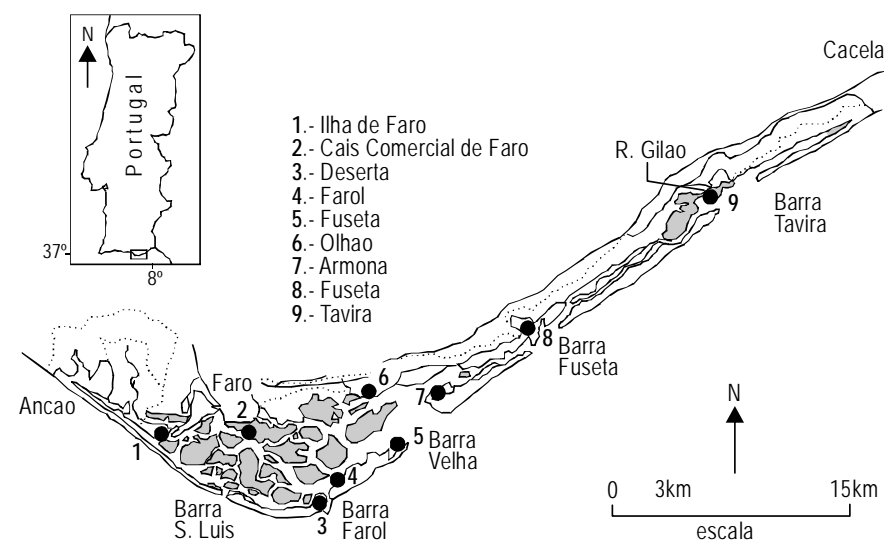

Figure 1. Location of the sampling sites of the mussel Mytilus galloprovincialis in the Ria Formosa lagoon (Portugal).

Figura 1. Localización de las estaciones de muestreo del mejillón Mytilus galloprovincialis en la Ría Formosa (Portugal). a la estación 9 (Tavira). En todas las estaciones se recolectaron alrededor de 20 individuos con un intervalo de talla de 5 a $7 \mathrm{~cm}$. En el laboratorio los especímenes fueron depurados durante $48 \mathrm{~h}$ para eliminar su contenido estomacal. Cada muestra fue etiquetada y congelada a $-20^{\circ} \mathrm{C}$ hasta su análisis posterior. Se descongelaron seis mejillones de cada estación de muestreo y se registró la longitud, ancho, altura, sexo y etapa de maduración de cada organismo. Se quitó el biso de los organismos y toda su parte comestible se colocó en un recipiente de teflón. Se utilizó un horno de microondas de alto rendimiento para secar y digerir las muestras de tejido. Para la digestíon se añadieron $4 \mathrm{~mL}$ de $\mathrm{HNO}_{3}$ al $69 \%$ de Aristar y $1 \mathrm{~mL}$ de $\mathrm{H}_{2} \mathrm{O}_{2}$ al $30 \%$ de Sigma.

\section{Análisis de metales}

Los metales fueron cuantificados mediante un espectrofotómetro de absorción atómica Perkin-Elmer Analyst 800. El Zn se determinó con llama y Ag, $\mathrm{Cd}, \mathrm{Cr}, \mathrm{Cu}, \mathrm{Ni}$ y $\mathrm{Pb}$ con horno de grafito.

Se utilizó material de referencia certificado para validar los resultados, en particular TORT-1 (hepatopáncreas desgrasado de langosta, Homarus americanus) y LUTS-1 (hepatopáncreas no desgrasado de langosta, H. americanus) del Consejo Nacional de Investigación de Canadá. Las recuperaciones de todos los metales, con excepción de $\mathrm{Pb}$ y Zn, varió de $80 \%$ a $120 \%$. Las concentraciones de todos los elementos se reportan como $\mathrm{mg} \mathrm{g}^{-1}$ de peso seco.

\section{Análisis estadístico}

Se determinaron la concentración media, la desviación estándar y el coeficiente de variación de cada metal en los nueve sitios de muestreo. Para verificiar las diferencias en la concentración de metales entre las estaciones, se aplicó una prueba de varianza no paramétrica de Kruskal-Wallis. Las hipótesis nula y alternativa fueron: $\mathrm{H}_{0}=$ la concentración de metales es igual entre estaciones y $\mathrm{H}_{1}=$ la concentración de metales es diferente entre estaciones. Se estableció un nivel de significancia de $5 \%$.

Los tratamientos estadísticos también incluyeron un método de clasificación numérica, el análisis de conglomerados (CA), así como un método de ordenación, el análisis de componentes principales (PCA). Para reducir los efectos de diferentes escalas de medición en diferentes caracteres, se estandarizó la matriz de datos (por substracción y reducción). Se seleccionó el coeficiente de correlación para determinar las similitudes entre los sitios de muestreo (modo Q) y los metales (modo R). El método de conglomeración seleccionado para el CA fue el método de par-grupo no ponderado por promedios aritméticos (UPGMA) y en ambos análisis la matriz de datos se compone de las concentraciones medias de cada metal en las nueve estaciones. La paquetería utilizada para CA y PCA fue NTSYS-PC (sistema de taxonomía numérica y análisis multivariante para microcomputadora IBM PC), versión 2.02 . 
principal component analysis (PCA). In order to reduce the effects of different scales of measurement in different characters, the data matrix was standardized (by subtraction and reduction). The correlation coefficient was selected to determine the similarities between sampling sites (mode Q) and metals (mode R). The method of agglomeration selected for the CA was the UPGMA (unweighted pair-group method using arithmetic averages) and in both analyses the data matrix consisted of the average concentrations of each metal at the nine sites. The software used for the CA and PCA was NTSYS-PC (numerical taxonomy and multivariate analysis system for IBM PC microcomputer), version 2.02 .

\section{Results}

Figure 2 shows the mean concentrations $( \pm$ standard deviation) of $\mathrm{Ag}, \mathrm{Cd}, \mathrm{Cr}, \mathrm{Cu}, \mathrm{Ni}, \mathrm{Pb}$ and $\mathrm{Zn}$ in the edible part of $M$. galloprovincialis at the nine sites.

The concentrations of Ag ranged from $0.0036 \pm$ $0.0021 \mathrm{mg} \mathrm{g}^{-1}$ at site 3 (Deserta) to $0.0082 \pm 0.0021 \mathrm{mg} \mathrm{g}^{-1}$ at site 1 (Ilha de Faro) (fig. 2). The differences in Ag among the sites were statistically significant $(P<0.05)$. The Ag concentrations were generally lower in the areas near inlets, namely sites 3 (Deserta) and 4 (Farol), with values of $0.0036 \pm$ 0.0021 and $0.004 \pm 0.0012 \mathrm{mg} \mathrm{g}^{-1}$, respectively.

The concentrations of Cd ranged from $0.36 \pm 0.04$ to $0.69 \pm$ $0.23 \mathrm{mg} \mathrm{g}^{-1}$ dry weight, the highest concentrations occurring at stations 3 (Deserta), 4 (Farol) and 9 (Tavira). These concentrations were significantly different from the other sampling sites $(P<0.05)$. The lowest concentrations were found at sites 1,5 and 6.

The concentrations of $\mathrm{Cr}$ ranged from $0.46 \pm 0.08$ to $1.01 \pm$ $0.61 \mathrm{mg} \mathrm{g}^{-1}$. The highest $\mathrm{Cr}$ concentrations were found at site 2 (Cais Comercial de Faro), which was significantly different from all the other sites $(P<0.05)$. Between the other sites there was no significant spatial variability of $\mathrm{Cr}$ concentrations.

In comparison to the other metal concentrations determined in the edible part of mussels from the Ria Formosa lagoon, $\mathrm{Cu}$ levels did not show any significant spatial variability (4.57 \pm 1.21 to $6.35 \pm 1.22 \mathrm{mg} \mathrm{g}^{-1}$ ). However, the highest concentrations were recorded at sites 1 (5.82 \pm 1.52$), 2$ (6.35 \pm 1.22$)$, 6 (5.62 \pm 0.87$)$ and 7 (6.00 \pm 0.96$)$.

The concentrations of $\mathrm{Ni}$ in the whole soft tissues ranged from $0.22 \pm 0.04$ to $0.61 \pm 0.32 \mathrm{mg} \mathrm{g}^{-1}$. The highest $\mathrm{Ni}$ concentrations occurred at sites 1 (0.61 \pm 0.32$), 7$ (0.52 \pm 0.14$)$ and 9 $(0.47 \pm 0.24)$, and were significantly different from the other sites $(P<0.05)$.

The concentrations of $\mathrm{Pb}$ ranged from $0.84 \pm 0.34$ to $2.89 \pm$ $0.96 \mathrm{mg} \mathrm{g}^{-1}$. The highest $\mathrm{Pb}$ concentrations occurred at station 9 (2.89 \pm 0.96$)$, which was significantly different from the other parts of the lagoon. The lowest concentrations were found at sites $1(1.24 \pm 0.16), 2(0.84 \pm 0.34), 5(1.10 \pm 0.36)$ and $7(1.19 \pm 0.08)$.

In contrast to $\mathrm{Cu}, \mathrm{Zn}$ concentrations in the mussels showed greater variability, ranging from $156 \pm 41$ to $321 \pm 120 \mathrm{mg} \mathrm{g}^{-1}$.

\section{Resultados}

En la figura 2 se muestran las concentraciones medias $( \pm$ la desviación estándar) de Ag, Cd, $\mathrm{Cr}, \mathrm{Cu}, \mathrm{Ni}, \mathrm{Pb}$ y Zn en la parte comestible de $M$. galloprovincialis de las nueve estaciones.

Las concentraciones de $\mathrm{Ag}$ presentaron un intervalo de $0.0036 \pm 0.0021 \mathrm{mg} \mathrm{g}^{-1}$ en la estación 3 (Deserta) a $0.0082 \pm$ $0.0021 \mathrm{mg} \mathrm{g}^{-1}$ en la estación 1 (Ilha de Faro) (fig. 2). Las diferencias en $\mathrm{Ag}$ entre sitios fueron estadísticamente significativas $(P<0.05)$. Las concentraciones de Ag generalmente fueron menores en las áreas cerca de las entradas, esto es en las estaciones 3 (Deserta) y 4 (Farol), con valores de $0.0036 \pm 0.0021$ y $0.004 \pm 0.0012 \mathrm{mg} \mathrm{g}^{-1}$, respectivamente.

Las concentraciones de Cd variaron de $0.36 \pm 0.04$ a $0.69 \pm$ $0.23 \mathrm{mg} \mathrm{g}^{-1}$ peso seco, registrándose las concentraciones más altas en las estaciones 3 (Deserta), 4 (Farol) y 9 (Tavira). Estas concentraciones son significativamente diferentes que las de los otros sitios de muestreo $(P<0.05)$. Las concentraciones más bajas se encontraron en las estaciones 1,5 y 6 .

Las concentraciones de Cr variaron de $0.46 \pm 0.08$ a $1.01 \pm$ $0.61 \mathrm{mg} \mathrm{g}^{-1}$. Las concentraciones mayores se presentaron en la estación 2 (Cais Comercial de Faro), que fue significativamente diferente que todos los demás sitios $(P<0.05)$. No se encontró una variabilidad espacial significativa de las concentraciones de $\mathrm{Cr}$ entre los otros sitios.
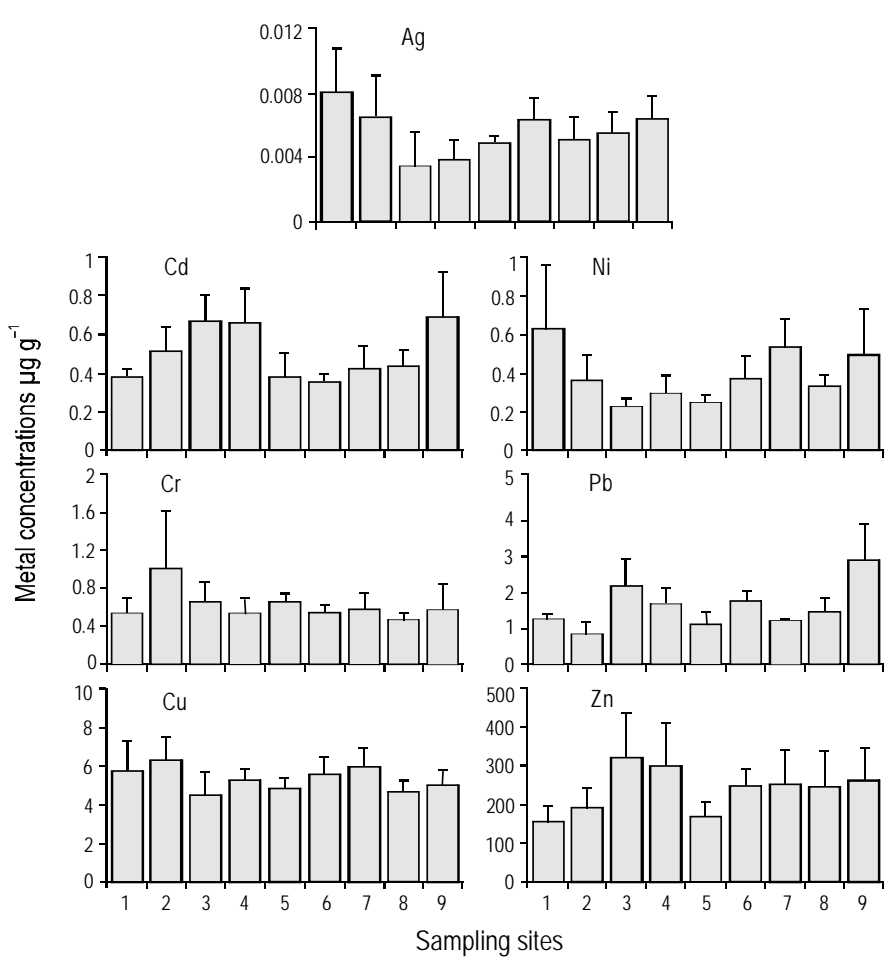

Figure 2. Metal concentrations, in $\mu \mathrm{g} \mathrm{g} \mathrm{g}^{-1}$ dry weight (mean + standard deviation), in Mytilus galloprovincialis from various sites (see fig. 1 for site identification): $\mathrm{Ag}, \mathrm{Cd}, \mathrm{Cr}, \mathrm{Cu}, \mathrm{Ni}, \mathrm{Pb}$ and $\mathrm{Zn}$.

Figura 2. Concentraciones de metales, en $\mu \mathrm{g} \mathrm{g}^{-1}$ peso seco (media + desviación estándar), en Mytilus galloprovincialis de varios sitios (ver fig. 1): $\mathrm{Ag}, \mathrm{Cd}, \mathrm{Cr}, \mathrm{Cu}, \mathrm{Ni}, \mathrm{Pb}$ y $\mathrm{Zn}$. 
Similarly to $\mathrm{Cd}$, the highest concentrations of $\mathrm{Zn}$ were also found at sites $3(321 \pm 120)$ and $4(301 \pm 109)$.

Data were treated together and CA was performed. The CA in mode Q is presented in figure 3a. As can be seen, the sampling sites were divided into two main groups. The first one includes sites 1, 2, 5, 6 and 7, whereas the second one includes sites 3, 4, 8 and 9. The correlation matrix between the sites (table 1) shows that, in the first group, the most similar sites are

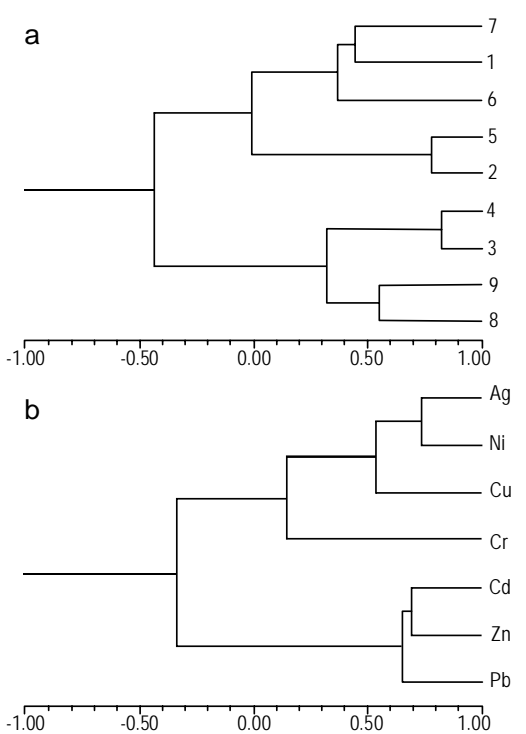

Figure 3. Cluster analysis. Dendograms obtained with UPGMA method and correlation coefficient: (a) mode Q (sites) and (b) mode R (metals) (see fig. 1 for site identification).

Figura 3. Análisis de conglomerados. Los dendrogramas se obtuvieron con el método UPGMA y coeficiente de correlación: (a) modo Q (estaciones de muestreo) y (b) modo R (metales) (ver fig. 1 para la identificación de estaciones).
En comparación con las concentraciones de los otros metales en la parte comestible de mejillones de la Ria Formosa, los niveles de $\mathrm{Cu}$ no presentaron una variabilidad espacial significativa ( $4.57 \pm 1.21$ a $\left.6.35 \pm 1.22 \mathrm{mg} \mathrm{g}^{-1}\right)$; sin embargo, las concentraciones más elevadas fueron registradas en las estaciones 1 (5.82 \pm 1.52$), 2$ (6.35 \pm 1.22$), 6(5.62 \pm 0.87) \mathrm{y}$ 7 (6.00 \pm 0.96$)$.

Las concentraciones de $\mathrm{Ni}$ en el tejido blando oscilaron entre $0.22 \pm 0.04$ y $0.61 \pm 0.32 \mathrm{mg} \mathrm{g}^{-1}$. Las concentraciones mayores se presentaron en las estaciones 1 (0.61 \pm 0.32$), 7$ $(0.52 \pm 0.14)$ y $9(0.47 \pm 0.24)$, y fueron significativamente diferentes a las de los otros sitios $(P<0.05)$.

Las concentraciones de $\mathrm{Pb}$ variaron de $0.84 \pm 0.34$ a $2.89 \pm$ $0.96 \mathrm{mg} \mathrm{g}^{-1}$. Las concentraciones más altas se presentaron en la estación 9 (2.89 \pm 0.96$)$, que fue significativamente diferente a otras partes de la laguna. Las concentraciones más bajas se registraron en las estaciones $1(1.24 \pm 0.16), 2$ (0.84 \pm 0.34$)$, $5(1.10 \pm 0.36)$ y $7(1.19 \pm 0.08)$.

En contraste con las concentraciones de $\mathrm{Cu}$, las de $\mathrm{Zn}$ en los mejillones mostraron mayor variabilidad, con un intervalo de $156 \pm 41$ a $321 \pm 120 \mathrm{mg} \mathrm{g}^{-1}$. Al igual que las de $\mathrm{Cd}$, las concentraciones mayores de Zn también fueron encontradas en las estaciones $3(321 \pm 120)$ y 4 (301 \pm 109$)$.

Los datos fueron tratados juntos y se realizó el CA. En la figura 3a se presenta el CA en modo Q. Se puede apreciar que los sitios de muestreo se dividieron en dos grupos principales. El primero incluye las estaciones 1, 2, 5, 6 y 7, mientras que el segundo incluye las estaciones 3, 4, 8 y 9. La matriz de correlación entre sitios (tabla 1) muestra que, en el primer grupo, los sitios más similares son los que se localizan en el canal principal de Faro-Olhão, es decir las estaciones 2 y $5(r=0.779)$, seguidos por las estaciones 1, 6 y 7. En el otro grupo, es posible distinguir dos subgrupos, uno que incluye las estaciones cerca de las entradas ( 3 y 4 ) y el otro que incluye las estaciones

Table 1. Correlation matrix between sites (mode Q): 1, Ilha de Faro; 2, Cais Comercial de Faro; 3, Deserta; 4, Farol; 5, Culatra; 6, Olhão; 7, Armona; 8, Fuseta; 9, Tavira.

Tabla 1. Matriz de correlación entre las estaciones de muestreo (modo Q): 1, Ilha de Faro; 2, Cais Comercial de Faro; 3, Deserta; 4, Farol; 5, Culatra; 6, Olhão; 7, Armona; 8, Fuseta; 9, Tavira.

\begin{tabular}{|c|c|c|c|c|c|c|c|c|c|}
\hline & 8 & 7 & 4 & 5 & 6 & 2 & 1 & 3 & 9 \\
\hline 7 & 1.000 & & & & & & & & \\
\hline 4 & -0.154 & 1.000 & & & & & & & \\
\hline 5 & -0.356 & -0.564 & 1.000 & & & & & & \\
\hline 6 & 0.308 & -0.451 & -0.115 & 1.000 & & & & & \\
\hline 2 & 0.145 & -0.441 & 0.779 & -0.075 & 1.000 & & & & \\
\hline 1 & 0.443 & -0.821 & 0.099 & 0.420 & 0.223 & 1.000 & & & \\
\hline 3 & -0.530 & 0.822 & -0.223 & -0.501 & -0.461 & -0.945 & 1.000 & & \\
\hline 9 & -0.585 & 0.290 & -0.334 & -0.252 & -0.786 & -0.228 & 0.499 & 1.000 & \\
\hline 8 & -0.306 & 0.177 & -0.512 & 0.229 & -0.777 & -0.101 & 0.307 & 0.548 & 1.000 \\
\hline 7 & 1.000 & & & & & & & & \\
\hline
\end{tabular}


those on the main Faro-Olhão channel, namely stations 2 and 5 ( $r=0.779$ ), and secondly sites 1,6 and 7 . In the other group it is possible to distinguish two subgroups, one including the sites near inlets (3 and 4) and the other the sites in the eastern zone of Ria Formosa (8 and 9). The most similar sites in these subgroups are stations 3 and 4, with a correlation coefficient of $r=0.822(P<0.05)$.

The CA in mode $\mathrm{R}$ is represented in figure $3 \mathrm{~b}$. In this dendogram metals are divided into two main groups (the correlation matrix between the seven metals is shown in table 2). The first group includes $\mathrm{Ag}, \mathrm{Ni}, \mathrm{Cu}$ and $\mathrm{Cr}$ and the second $\mathrm{Cd}$, $\mathrm{Zn}$ and $\mathrm{Pb}$. There is a significant correlation between $\mathrm{Ag}$ and $\mathrm{Ni}(r=0.737)$ and between $\mathrm{Cd}$ and $\mathrm{Zn}(r=0.695)$ bioaccumulated in the mussels' whole soft tissue. The concentrations of $\mathrm{Pb}$ are also related to $\mathrm{Cd}$ and $\mathrm{Zn}(r=0.692)$ and those of $\mathrm{Cu}$ are to $\mathrm{Ag}$ and $\mathrm{Ni}(r=0.548)$. There is no significant relationship between $\mathrm{Cr}$ and Ag, nor between $\mathrm{Ni}$ and $\mathrm{Cu}(r=0.120)(P>$ 0.05).

The application of PCA presented in figure 4 complements the results obtained by CA, and with the biplot it is possible to observe sites (mode Q) and metals (mode R) simultaneously. The first axis (PC1) accounts for $46 \%$ of the total variation, while the second (PC2) for only about 25\%. PC1 and PC2 represent about $71 \%$ of the total variability. As in the CA, the division of the sites (mode Q) is probably related to their location in the Ria Formosa. Thus, three main areas can be distinguished in the lagoon: the area near one of the inlets (sites 3 and 4), the western area (sites 1, 2, 5, 6 and 7) and the eastern area (sites 8 and 9).

From figure 4 it is possible to observe that the metals occur near the sites in which their concentrations are higher. Hence, $\mathrm{Ni}$ and $\mathrm{Ag}$ are closer to site 1; Pb to site 9; $\mathrm{Zn}$ and $\mathrm{Cd}$ to sites 3, 4 and 9; Cr to sites 2 and 5; and Cu to sites 1, 2 and 7.

\section{Discussion}

Metal concentrations in whole soft tissues of mussels revealed that in spite of the considerable water renovation that occurs between tides, specific metal differences are observed among sites. These differences detected for certain metals highlight the presence of important pollution sources. en la zona oriental de la Ría Formosa (8 y 9). Los sitios 3 y 4 fueron los más similares en estos subgrupos, con un coeficiente de correlación de $r=0.822(P<0.05)$.

En la figura $3 b$ se presenta el CA en modo R. En este dendograma los metales se dividen en dos grupos principales (la matriz de correlación entre los siete metales se muestra en la tabla 2). El primer grupo incluye Ag, $\mathrm{Ni}, \mathrm{Cu}$ y $\mathrm{Cr}$, y el segundo $\mathrm{Cd}, \mathrm{Zn}$ y $\mathrm{Pb}$. Existe una correlación significativa entre Ag y $\mathrm{Ni}$ ( $r=0.737)$ y entre $\mathrm{Cd}$ y $\mathrm{Zn}(r=0.695)$ bioacumulados en el tejido blando entero de los mejillones. Las concentraciones de $\mathrm{Pb}$ también se relacionan con $\mathrm{Cd}$ y $\mathrm{Zn}(r=0.692)$ y las de $\mathrm{Cu}$ con Ag y Ni $(r=0.548)$. No hay una relación significativa entre Cr y Ag, ni entre Ni y Cu $(r=0.120)(P>0.05)$.

La aplicación del PCA (fig. 4) complementa los resultados obtenidos con el CA, y con la gráfica tipo biplot es posible observar las estaciones (modo Q) y los metales (modo R) simultáneamente. El primer eje (PC1) explica 46\% de la variación total, mientras que el segundo (PC2) sólo alrededor de 25\%. Los PC1 y PC2 representan alrededor de 71\% de la variabilidad total. Así como en el CA, la división de los sitios (modo Q) probablemente se relaciona con su localización en la Ría Formosa. Por tanto, se pueden distinguir tres zonas principales en la laguna: la zona cerca de las entradas (estaciones 3 y 4), la zona occidental (estaciones 1, 2, 5, 6 y 7) y la zona oriental (estaciones 8 y 9).

La figura 4 muestra que los metales se encuentran cerca de los sitios donde sus concentraciones son mayores. Así, Ni y Ag están más cerca de la estación 1; Pb de la estación 9; Zn y Cd de las estaciones 3, 4 y 9; Cr de las estaciones 2 y 5; y Cu de las estaciones 1,2 y 7.

\section{Discusión}

Las concentraciones de metales en los tejidos suaves enteros de los mejillones muestran que a pesar de la considerable renovación de agua entre mareas, existen diferencias específicas de metales entre las estaciones. Estas diferencias entre algunos metales claramente indican la presencia de importantes fuentes de contaminación.

Table 2. Correlation matrix between metals (mode R). Tabla 2. Matriz de correlación entre metales (modo R).

\begin{tabular}{l|rrrrrrr}
\multicolumn{1}{c}{} & $\mathrm{Ag}$ & $\mathrm{Cd}$ & $\mathrm{Cr}$ & $\mathrm{Cu}$ & $\mathrm{Ni}$ & $\mathrm{Pb}$ & $\mathrm{Zn}$ \\
\cline { 2 - 8 } $\mathrm{Ag}$ & 1.000 & & & & & & \\
$\mathrm{Cd}$ & -0.483 & 1.000 & & & & & \\
$\mathrm{Cr}$ & 0.120 & 0.061 & 1.000 & & & & \\
$\mathrm{Cu}$ & 0.523 & -0.351 & 0.487 & 1.000 & & & \\
$\mathrm{Ni}$ & 0.737 & -0.275 & -0.172 & 0.548 & 1.000 & & \\
$\mathrm{~Pb}$ & -0.184 & 0.692 & -0.376 & -0.546 & -0.032 & 1.000 & \\
$\mathrm{Zn}$ & -0.724 & 0.695 & -0.304 & -0.405 & -0.384 & 0.617 & 1.000
\end{tabular}


A metal associated with human activities is Ag, of which the natural sources are practically absent in coastal areas and estuaries (Muñoz-Barbosa et al., 2000). Contamination by Ag can be due to various sources, the most likely being its use in photography, X-rays, batteries and electric equipment (Clark, 2001). The highest Ag concentrations observed in the mussels from Ria Formosa occurred at sites 1, 2, 6 and 9. Sites1, 2 and 6 are located in an interior zone (with less efficient water renovation) and, therefore, more susceptible to the deposition of contaminated suspended particles. Site 9 is located in a channel where the renovation of water is higher, but it is near an urbanized area directly influenced by domestic and industrial wastewater discharges. Furthermore, it is located near the impact of the Gilão River, which can transport other contaminated materials from the inner part of the land.

The concentration of Ag in the edible part of the mussels is very low in comparison to other coastal areas (table 3).

The concentrations of $\mathrm{Cd}$ in the Ria Formosa lagoon are higher at sites 3, 4 and 9. The concentrations observed at site 9 could be related to urban discharges and agricultural runoffs. The transport of fertilizers and pesticides from agriculture can constitute an important non-point source of $\mathrm{Cd}$ to the marine environment (Laws, 1993). On the other hand, site 9 is located in the area of influence of the Gilão River, where the changes in salinity in surrounding areas can enhance the bioavailability of Cd (Wright, 1995). At sites 3 and 4 there is a strong oceanic influence (Andrade, 1990). In this case, the sources of Cd could be related to the resuspension of sediments or to the transport of Cd from the ocean by physical processes, like advection and upwelling (Munoz-Barbosa et al., 2000), which are known to occur occasionally in that area; these processes have also been related to $\mathrm{Cd}$ levels in the water column (results not published).

In comparison to other studies it is possible to say that $\mathrm{Cd}$ concentrations in the Ria Formosa lagoon are low (table 3). However, considering the Cd value of $0.5 \mathrm{mg} \mathrm{g}^{-1}$ in the edible part of the mussel as an indicator of contamination by this metal (Burt and Scrimshaw, 1993), we can observe that Cd levels are slightly higher at a few sites (3, 4 and 9).

The $\mathrm{Cr}$ concentrations detected in the edible part of the mussels did not show any significant variation along the Ria Formosa, except for site 2, where the concentrations were significantly higher. This could be related to industrial discharges, which according to Walsh and O'Halloran (1998) constitute an important source of $\mathrm{Cr}$ in the environment. Another significant source could be the oxidation of the metallic structures and ships found at that site, possibly releasing $\mathrm{Cr}$ into the water (Irwin et al., 1997).

The Cr levels in the Ria Formosa mussels are lower (table 3) than those reported for other geographical areas, except in comparison to those of Mytilus edulis in Canada (Lobel et al., 1990). The Ria Formosa specimens reveal $\mathrm{Cr}$ concentrations higher than $0.5 \mathrm{mg} \mathrm{g}^{-1}$, which according to Burt and Scrimshaw (1993) is an indicator of $\mathrm{Cr}$ contamination.

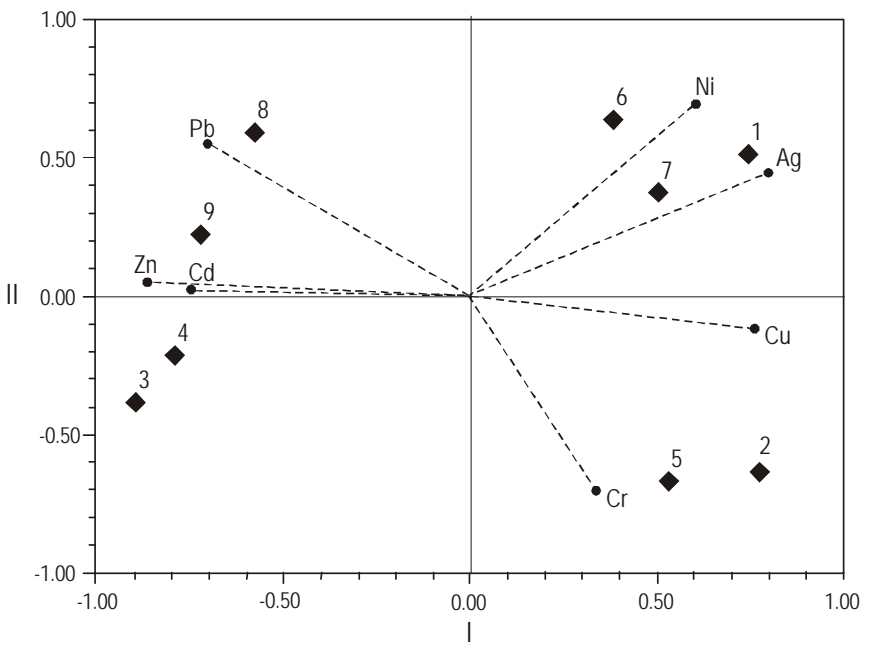

Figure 4. Principal component analysis. Biplot: simultaneous projection of sites (mode Q) and metals (mode R) in the first two axes (PC1 and PC2). See figure 1 for site identification $(\bullet)$.

Figura 4. Análisis de componentes principales. Biplot: proyección simultánea de las estaciones de muestreo (modo Q) y los metales (modo $\mathrm{R}$ ) en los dos primeros ejes (PC1 y PC2). Ver figura 1 para la identificación de estaciones $(\bullet)$.

El Ag es un metal asociado con actividades humanas, del cual casi no hay fuentes naturales en áreas costeras y estuarios (Muñoz-Barbosa et al., 2000). La contaminación por Ag puede deberse a varias fuentes, el más probable siendo su uso en la fotografía, rayos X, baterías y equipo eléctrico (Clark, 2001). Las mayores concentraciones de Ag en los mejillones de la Ría Formosa se registraron en las estaciones 1, 2, 6 y 9. Las estaciones 1, 2 y 6 se localizan en una zona interior (con renovación de agua menos eficiente) y, por tanto, son más susceptibles al depósito de partículas suspendidas contaminadas. La estación 9 se localiza en un canal donde hay mayor renovación de agua, pero está cerca de una zona urbanizada afectada directamente por el vertido de aguas residuales domésticas e industriales. Asimismo, se localiza cerca del impacto del Río Gilão, que puede transportar otros materiales contaminados desde tierra adentro.

La concentración de Ag en la parte comestible de los mejillones es muy baja en comparación con otras zonas costeras (tabla 3).

Las concentraciones de Cd en la Ría Formosa son mayores en las estaciones 3, 4 y 9. Las concentraciones encontradas en la estación 9 pueden estar relacionadas con descargas urbanas y escurrimientos agrícolas. El transporte de fertilizantes y pesticidas de la agricultura puede ser una fuente importante no puntual de Cd al medio marino (Laws, 1993). Por otro lado, la estación 9 se localiza en la zona de influencia del Río Gilão, donde los cambios en salinidad en las zonas circundantes puede aumentar la biodisponibilidad de Cd (Wright, 1995). En las estaciones 3 y 4 hay una fuerte influencia oceánica (Andrade, 1990). En este caso, las fuentes de Cd pueden estar 
Table 3. Metal concentrations ( $\mathrm{mg} \mathrm{g}^{-1} \mathrm{dry}$ weight) in the edible soft tissue of Mytilus spp. from different geographical areas.

Tabla 3. Concentraciones de metales ( $\mathrm{mg} \mathrm{g}^{-1}$ peso seco) en el tejido blando comestible de Mytilus spp. de diferentes zonas geográficas.

\begin{tabular}{|c|c|c|c|c|c|c|c|c|}
\hline Species & Area & $\mathrm{Ag}$ & $\mathrm{Cd}$ & $\mathrm{Cr}$ & $\mathrm{Cu}$ & $\mathrm{Ni}$ & $\mathrm{Pb}$ & $\mathrm{Zn}$ \\
\hline \multirow[t]{2}{*}{$\begin{array}{l}\text { Mytilus } \\
\text { galloprovincialis }\end{array}$} & $\begin{array}{l}\text { South coast of } \\
\text { Portugal }^{1}\end{array}$ & & $1.30-2.70$ & & $4.80-7.00$ & $0.37-0.77$ & & 186-398 \\
\hline & Italy $^{2}$ & & $0.73-4.54$ & $0.37-20.38$ & 5.08-20.89 & $0.08-24.48$ & $6.18-80.26$ & 82-185 \\
\hline \multirow[t]{3}{*}{ Mytilus edulis } & United Kingdom ${ }^{3}$ & $0.02-16.90$ & $0.40-65.40$ & $<0.20-7.20$ & $6-262$ & $0.50-12$ & $1.70-105$ & $45-579$ \\
\hline & East coast USA ${ }^{4}$ & $0.08-0.16$ & $0.96-1.30$ & & $6.30-9.10$ & $0.87-1.20$ & 1.40 & $67-90$ \\
\hline & Canada $^{5}$ & $0.05 \pm 0.01$ & $0.90 \pm 0.10$ & $0.45 \pm 0.04$ & $5.60 \pm 0.60$ & & $0.96 \pm 0.26$ & $68.7 \pm 95$ \\
\hline \multirow{2}{*}{$\begin{array}{l}\text { Mytilus } \\
\text { californianus }\end{array}$} & West coast USA ${ }^{6}$ & $0.20-0.91$ & $4.80-70.20$ & & $7.10-89.00$ & & & $113-321$ \\
\hline & West coast USA ${ }^{7}$ & $0.01-1.63$ & $0.59-12.93$ & & $4.00-9.10$ & & $0.00-2.80$ & \\
\hline
\end{tabular}

${ }^{1}$ Bebianno and Machado (1997), ${ }^{2}$ Widdows et al. (1997), ${ }^{3}$ Bryan et al. (1985), ${ }^{4}$ Lauenstein et al. (1990), ${ }^{5}$ Lobel et al. (1990), ${ }^{6}$ Gutiérrez-Galindo et al. (1999), ${ }^{7}$ Muñoz-Barbosa et al. (2000).

The $\mathrm{Cu}$ concentrations in the Ria Formosa mussels, like those of Cr, show a certain homogeneity between sites. Considering that the most significant $\mathrm{Cu}$ sources are the urban discharges, release from metallic structures, antifouling paints and fertilizers (Clark, 2001), one could assume that the highest concentrations occurred at sites near urbanized areas, like stations 2, 6 and 9. This reduced variation of $\mathrm{Cu}$ concentrations can be related to the fact that mussels easily eliminate this metal; therefore, $\mathrm{Cu}$ levels in this lagoon could be underestimated (Langston and Spence, 1995; Brown and Depledge, 1998).

The $\mathrm{Cu}$ levels in the Ria Formosa mussels are lower than those observed by several authors in different coastal areas (table 3), but they are higher than $1.5 \mathrm{mg} \mathrm{g}^{-1}$, which indicates contamination by this metal (Burt and Scrimshaw, 1993).

The Ni concentrations in the Ria Formosa mussels were highest at sites 1, 7 and 9. This metal enters the marine environment essentially through urban and industrial discharges (Irwin et al., 1997). The levels at site 1 could be related to domestic inputs, the major source of contamination at this site (Newton, 1995). At sites 7 and 9 the contamination is probably due to industrial and domestic inputs, which occur near both sites. Even though site 7 is far from the main source of contamination, the water circulation in Ria Formosa could explain the transport of $\mathrm{Ni}$ from those areas.

The concentration of $\mathrm{Ni}$ in the Ria Formosa mussels is lower than those in mussels from coastal areas of Europe and North America (table 3).

The highest $\mathrm{Pb}$ levels occur at sites 3 and 9. According to Cortesão et al. (1986) and Bebianno (1995), the highest concentrations of $\mathrm{Pb}$ in the Ria Formosa are related to the input by urban discharges and the use of $\mathrm{Pb}$ in boat fuel. The Pb concentrations observed at site 9 are probably due to urban discharges and boat fuel, since there is a lot of maritime traffic in this area. Additional sources could be road runoffs (Sadiq, 1992) and relacionadas con la resuspension de sedimento o con el transporte de Cd del océano por procesos físicos, como advección o surgencias (Munoz-Barbosa et al., 2000), que ocasionalmente se presentan en esa zona; estos procesos también se han relacionado con los niveles de $\mathrm{Cd}$ en la columna de agua (resultados no publicados).

En comparación con otros estudios, es posible afirmar que las concentraciones de $\mathrm{Cd}$ en la Ría Formosa son bajas (tabla 3). No obstante, considerando que el valor de Cd de $0.5 \mathrm{mg} \mathrm{g}^{-1}$ en la parte comestible del mejillón es un indicador de la contaminación por este metal (Burt y Scrimshaw, 1993), se observó que en algunas estaciones (3, 4 y 9), los niveles de Cd son ligeramente mayores.

Las concentraciones de Cr detectadas en la parte comestible del mejillón no mostraron alguna variación significativa a lo largo de la Ría Formosa, con excepción de la estación 2, donde las concentraciones fueron ligeramente mayores. Esto podría estar relacionado con vertidos industriales, las cuales según Walsh y O’Halloran (1998) constituyen una fuente importante de $\mathrm{Cr}$ en el medio. Otra fuente significativa podría ser la liberación de Cr en el agua por la oxidación de estructuras metálicas y embarcaciones en ese sitio (Irwin et al., 1997).

Los niveles de Cr en los mejillones de la Ría Formosa son menores que los reportados para otras zonas geográficas (tabla 3), excepto en comparación con los de Mytilus edulis en Canadá (Lobel et al., 1990). Los especímenes de la Ría Formosa tienen concentraciones de $\mathrm{Cr}$ mayores que $0.5 \mathrm{mg} \mathrm{g}^{-1}$, valor que según Burt y Scrimshaw (1993) demuestra contaminación por Cr.

Las concentraciones de $\mathrm{Cu}$, como las de $\mathrm{Cr}$, en los mejillones de la Ría Formosa muestran cierta homogeneidad entre sitios. Considerando que las fuentes principales de $\mathrm{Cu}$ son las descargas urbanas, liberación de estructuras metálicas, pinturas antiincrustantes y fertilizantes (Clark, 2001), se puede suponer que las concentraciones más elevadas se presentaron en los 
atmospheric deposition (Laws, 1993). Similarly, Cortesão et al. (1986) also observed high levels of $\mathrm{Pb}$ at site 3 (Deserta), which is probably related to the intense maritime traffic in that area.

In comparison to other studies it is possible to say that $\mathrm{Pb}$ concentrations in the Ria Formosa mussels are lower than those found in the United Kingdom and Italy (table 3), but higher than those for M. edulis in Canada (Lobel et al., 1990) and for $M$. californianus on the western coast of the USA (Muñoz-Barbosa et al., 2000). Taking into account the level of $1 \mathrm{mg} \mathrm{g}^{-1}$ as an indicator of $\mathrm{Pb}$ contamination (Burt and Scrimshaw, 1993), one can say that the concentrations of $\mathrm{Pb}$ in the Ria Formosa mussels are higher than that level.

The concentrations of $\mathrm{Zn}$ show a similar distribution to that observed for $\mathrm{Cd}$, which is in agreement with Coimbra and Carraça's study (1990). Because Zn and Cd belong to the same group of metals (IIB), they possess a similar geochemical behaviour and so their distribution is usually very similar. The sources of $\mathrm{Zn}$ in this lagoon include industrial discharges, release from metallic structures and rubber materials (Hunter $e t$ al., 1995), probably occurring near sites 3, 4 and 9.

The $\mathrm{Zn}$ concentrations in the Ria Formosa mussels are lower than those observed by Bryan et al. (1985) in the United Kingdom, but higher than those observed by Lauenstein $e t$ al. (1990) on the eastern coast of the USA, by Lobel et al. (1990) in Canada and by Widdows et al. (1997) in Italy (table 3). The Ria Formosa mussels present Zn levels ten times higher than $30 \mathrm{mg} \mathrm{g}^{-1}$, which indicates $\mathrm{Zn}$ contamination (Burt and Scrimshaw, 1993).

With the application of CA and PCA in mode Q (by sites), there is a clear distinction between the sites located in the western area, eastern area and inlet area. In fact, one can divide Ria Formosa based on the water circulation. The water inflow splits the lagoon system into two main sectors: western and eastern; the latter is confined to the east of site 7 and is only connected during spring tide. This way the sources of contamination are restricted to a particular sector, separating sites 1,2 , 5, 6 and 7 from sites 8 and 9 .

The western sector is divided into two subgroups (figs. 3 , 4): one comprised by sites 1, 6 and 7, and the other by sites 2 and 5. This division is not related to the proximity of the sites, but to the influence of the respective water inlet, which in a way restricts the water that flows into a particular site, and to the type of discharges that occur nearby, which would confer similar metal concentrations.

The inlet area that includes sites 3 and 4 is more influenced by the sea, showing different metal concentrations than those observed in the other areas of the lagoon. At these sites water renovation occurs more frequently and so the impact of the metal discharges from the interior of the lagoon is inferior. Sites 3 and 4 are associated with the highest concentrations of $\mathrm{Cd}$ and $\mathrm{Zn}$, which can also come from the coastal zone. Another factor can be due to the regeneration of $\mathrm{Cd}$ and $\mathrm{Zn}$ in sitios cerca de zonas urbanizadas, como las estaciones 2, 6 y 9 . Esta variación reducida de las concentraciones de $\mathrm{Cu}$ puede estar asociada con el hecho de que los mejillones eliminan este metal con facilidad; por tanto, los niveles de $\mathrm{Cu}$ en esta laguna pueden estar subestimados (Langston y Spence, 1995; Brown y Depledge, 1998).

Los niveles de $\mathrm{Cu}$ en los mejillones de la Ría Formosa son menores que los observados por varios autores en diferentes zonas costeras (tabla 3), pero son mayores que $1.5 \mathrm{mg} \mathrm{g}^{-1}$, lo que indica contaminación por este metal (Burt y Scrimshaw, 1993).

Las concentraciones de $\mathrm{Ni}$ en los mejillones de la Ría Formosa fueron mayores en las estaciones 1,7 y 9. Este metal ingresa en el ambiente marino por medio de descargas urbanas e industriales (Irwin et al., 1997). Los niveles en la estación 1 pueden estar relacionados con vertidos domésticos, la principal fuente de contaminación en este sitio (Newton, 1995). En las estaciones 7 y 9 la contaminación problemente se deba a las descargas industriales y domésticas cerca de ambos sitios. Aunque la estación 7 se localiza lejos de la principal fuente de contaminación, la circulación de agua en la Ría Formosa puede explicar el transporte de $\mathrm{Ni}$ en esas zonas.

La concentración de Ni en los mejillones de la Ría Formosa es menor que en los mejillones de otras zonas costeras de Europa y Norte América (tabla 3).

Los mayores niveles de $\mathrm{Pb}$ se encontraron en las estaciones 3 y 9. De acuerdo con Cortesão et al. (1986) y Bebianno (1995), las concentraciones mayores en la Ría Formosa están relacionadas con las descargas urbanas y el uso de $\mathrm{Pb}$ en el combustible de barcos. Las concentraciones de $\mathrm{Pb}$ en la estación 9 probablemente están relacionadas con las descargas urbanas y el combustible de barcos, ya que hay mucho tráfico marítimo en esta zona. Fuentes adicionales podrían ser los escurrimientos de calles (Sadiq, 1992) y el depósito atmosférico (Laws, 1993). Similarmente, Cortesão et al. (1986) también observaron niveles altos de $\mathrm{Pb}$ en la estación 3 (Deserta), lo cual probablemente esté asociado con el tráfico marítimo en la zona.

En comparación con otros estudios, es posible afirmar que las concentraciones de $\mathrm{Pb}$ en los mejillones de la Ría Formosa son menores que los encontrados en el Reino Unido e Italia (tabla 3), pero mayores que los registrados para M. edulis en Canadá (Lobel et al., 1990) y para M. californianus en la costa occidental de EUA (Muñoz-Barbosa et al., 2000). Las concentraciones de $\mathrm{Pb}$ son mayores que el nivel de $1 \mathrm{mg} \mathrm{g}^{-1}$, el cual es indicativo de la contaminación por $\mathrm{Pb}$ (Burt y Scrimshaw, 1993).

La concentración de Zn muestra una distribución similar a la observada para $\mathrm{Cd}$, lo que concuerda con el estudio de Coimbra y Carraça (1990). En vista de que Zn y Cd pertenecen al mismo grupo de metales (IIB), éstos poseen un comportamiento geoquímico similar y, por ende, su distribución tiende a ser muy similar. Las fuentes de $\mathrm{Zn}$ en esta laguna son las descargas industriales, la liberación de estructuras metálicas y 
the water column, in a cycle similar to that of nutrients (Muñoz-Barbosa et al., 2000).

From the present work it is possible to conclude that metal concentrations in the Ria Formosa mussels decrease according to the order: $\mathrm{Zn}>\mathrm{Cu}>\mathrm{Pb}>\mathrm{Cr}>\mathrm{Cd}>\mathrm{Ni}>\mathrm{Ag}$. Also, three main areas can be distinguished in the Ria Formosa lagoon, related to the similarities in metal concentrations: a western zone that includes sites 1, 2, 5, 6 and 7; an eastern zone that includes sites 8 and 9; and an inlet zone that comprises sites 3 and 4. Comparatively, the metal concentrations exhibited in the edible part of the Ria Formosa mussels are inferior to those observed in mussels from coastal areas in Europe and USA. Therefore, metal levels in mussels can be used, together with the suspension-feeder $R$. decussatus, as bioindicators of metal contamination in this ecosystem.

\section{References}

Andrade, P. (1990). O Ambiente de Barreira da Ria Formosa, Algarve, Portugal. Dissertação de Doutoramento em Geologia do Ambiente. Departamento de Geologia da Universidade de Lisboa.

Bebianno, M.J. (1995). Effects of pollutants in the Ria Formosa Lagoon, Portugal. Sci. Total Environ., 171: 107-115.

Bebianno, M.J. and Machado, L.M. (1997). Concentrations of metals and metallothioneins in Mytilus galloprovincialis along the south coast of Portugal. Mar. Pollut. Bull., 34(8): 666-671.

Boening, D.W. (1999). An evaluation of bivalves as biomonitors of heavy metal pollution in marine waters. Environ. Monit. Assess., 55: 459-470.

Brown, M.T. and Depledge, M.H. (1998). Determinants of trace metal concentrations in marine organisms. In: W.J. Langston and M.J. Bebianno (eds.), Metal Metabolism in Aquatic Environments. Chapman and Hall, London, pp. 185-217.

Bryan, G.W., Langston, W.J., Humerstone, L.G. and Burt, G.R. (1985). A guide to the assessment of heavy metal contamination in estuaries using biological indicators. Occas. Publ. Mar. Biol. Assoc. UK, 1: 1-73.

Burt, J.S. and Scrimshaw, C.E. (1993). A comparative survey of heavy metals in the mussel Mytilus edulis from Cockburn Sound and surrounding waters. Environmental Protection Authority, Perth, Western Australia, Tech. Ser. No. 56, 27 pp.

Clark, R.B. (2001). Marine Pollution. 5th ed. Oxford University Press, New York, 237 pp.

Coimbra, J. and Carraça, S. (1990). Accumulation of Fe, Zn, Cu, and Cd during the different stages of the reproductive cycle in Mytilus edulis. Comp. Biochem. Physiol., 95C(2): 265-270.

Cortesão, C., Mendes, R. and Vale, C. (1986). Metais pesados em bivalves e sedimentos na Ria Formosa, Algarve. Bol. Inst. Nac. Invest. Pescas, No. 14: 3-28.

Goldberg, E.D., Bowen, V.T., Farrington, J.W., Harvey, G., Martin, J.H., Parker, P.L., Risebrough, R.W., Robertson, W., Schneider, E. and Gamble, E. (1978). The Mussel Watch. Environ. Conserv., 5(2): 101-125.

Gutiérrez-Galindo, E.A., Villaescusa-Celaya, J.A. and ArreolaChimal, A. (1999). Bioaccumulation of metals in mussels from four sites of the coastal region of Baja California. Cienc. Mar., 25(4): 557-578.

Hunter, C.L., Stephenson, M.D., Tjeerdema, R.S., Crosby, D.G., Ichiwaka, G.S., Goetzl, J.D., Paulson, K.S., Crane, D.B., Martin, M. and Newman, J.W. (1995). Contaminants in oysters in Kaneohe Bay, Hawaii. Mar. Pollut. Bull., 30(10): 646-654. los materiales de caucho (Hunter et al., 1995), probablemente cerca de las estaciones 3, 4 y 9.

Las concentraciones de $\mathrm{Zn}$ en los mejillones de la Ría Formosa son menores que los observados por Bryan et al. (1985) en el Reino Unido, pero mayores que los obtenidos por Lauenstein et al. (1990) en la costa oriental de EUA, por Lobel et al. (1990) en Canadá y por Widdows et al. (1997) en Italia (tabla 3). Los mejillones de la Ría Formosa presentan niveles de $\mathrm{Zn}$ diez veces mayores que $30 \mathrm{mg} \mathrm{g}^{-1}$, valor que indica contaminación por Zn (Burt y Scrimshaw, 1993).

Con la aplicación de CA y PCA en modo Q (por sitios), se obtiene una clara distinción entre las estaciones localizadas en la zona occidental, la zona oriental y la zona de entradas. Es más, se puede dividar la Ría Formosa con base en la circulación del agua. La entrada de agua divide el sistema lagunar en dos sectores principales: occidental y oriental; la segunda es confinada al este de la estación 7 y sólo se conecta durante las mareas vivas. Así, las fuentes de contaminación quedan restringidas a una zona en particular, separando las estaciones 1 , 2, 5, 6 y 7 de las estaciones 8 y 9 .

La zona occidental se divide en dos subgrupos (figs. 3,4 ): uno incluye las estaciones 1,6 y 7 , y el otro las estaciones 2 y 5. Esta división no está relacionada con la proximidad de los sitios, sino con la influencia de la entrada de agua respectiva, que de alguna forma limita el agua que fluye a un sitio en particular, y con el tipo de descargas que se presentan cerca, que podría conferir concentraciones de metales similares.

La zona de entradas que incluye las estaciones 3 y 4 recibe mayor influencia del mar, y las concentraciones de metales son diferentes que las obtenidas en otras zonas de la laguna. En estas estaciones, la renovación del agua ocurre con mayor frecuencia y, por tanto, el impacto de las descargas de metales del interior de la laguna es menor. Las estaciones 3 y 4 están asociadas con las concentraciones de Cd y Zn más elevadas, que también pueden venir de la zona costera. Otro factor puede ser la regeneración de $\mathrm{Cd}$ y $\mathrm{Zn}$ en la columna de agua, en un ciclo similar al de los nutrientes (Muñoz-Barbosa et al., 2000).

Del presente trabajo es posible concluir que las concentraciones de metales en los mejillones de la Ría Formosa disminuyen según el orden: $\mathrm{Zn}>\mathrm{Cu}>\mathrm{Pb}>\mathrm{Cr}>\mathrm{Cd}>\mathrm{Ni}>$ Ag. Asimismo, se distinguen tres zonas principales en la laguna en relación con similitudes en las concentraciones de metales: la zona occidental que incluye las estaciones $1,2,5$, 6 y 7; la zona oriental que incluye las estaciones 8 y 9; y la zona de las entradas de mar que incluye las estaciones 3 y 4 . Comparativamente, las concentraciones de metales encontradas en la parte comestible de mejillones de la Ría Formosa son menores que las observadas en mejillones de otras zonas costeras de Europa y EUA. Por tanto, los niveles de metales en los mejillones se pueden usar, junto con la especie suspensívora $R$. decussatus, como bioindicadores de la contaminación por metales en este ecosistema.

Traducido al español por Christine Harris. 
Irwin, R.J., VanMouwerik, M., Stevens, L., Seese, M.D. and Basham, W. (1997). Environmental Contaminants Encyclopedia. National Park Service, Water Resources Division, Fort Collins, Colorado.

Kennish, M.J. (1992). Ecology of Estuaries: Anthropogenic Effects. Marine Science Series, USA, 494 pp.

Langston, W.J. and Spence, S.K. (1995). Biological factors involved in metal concentrations observed in aquatic organisms. In: A. Téssier and D.R. Turner (eds.), Metal Speciation and Bioavailability in Aquatic Systems. Vol. 3. IUPAC, England, pp. 407-478.

Lauenstein, G.G., Robertson, A. and O’Connor, T.P. (1990). Comparison of trace metal data in mussels and oysters from a mussel watch programme of the 1970s with those from a 1980s programme. Mar. Pollut. Bull., 21(9): 440-447.

Laws, E.A. (1993). Aquatic Pollution. 2nd ed. John Wiley, USA, $611 \mathrm{pp}$.

Lobel, P.B., Belkhode, S.P., Jackson, S.E. and Longerich, H.P. (1990). Recent taxonomic discoveries concerning the mussel Mytilus: Implications for biomonitoring. Arch. Environ. Contam. Toxicol., 19: 508-512.

Matos, N.F., Partidário, M.R. and Oliveira, R. (1999). Estudo ambiental do "Projecto de requalificação do Sistema Lagunar da Ria Formosa". 6th National Conference of Environmental Quality, Vol. 3, Lisbon, pp. 479-491.

Mudge, S.M. and Bebianno, M.J. (1997). Sewage contamination following an accidental spillage in the Ria Formosa, Portugal. Mar. Pollut. Bull., 34(3): 163-170.
Muñoz-Barbosa, A., Gutiérrez-Galindo, E.A. and Flores-Muñoz, G. (2000). Mytilus californianus as an indicator of heavy metals on the northwest coast of Baja California, Mexico. Mar. Environ. Res., 49: 123-144.

Newton, A. (1995). The water quality of the Ria Formosa Lagoon, Portugal. Ph.D. Thesis, University of Wales, $226 \mathrm{pp}$.

Rainbow, P.S. (1995). Biomonitoring of heavy metal availability in the marine environment. Mar. Pollut. Bull., 31(4-12): 183-192.

Rainbow, P.S. (1996). Heavy metals in aquatic invertebrates. In: W.N. Beyer, G.H. Heinz and A.W. Redmon-Norwood (eds.). Environmental Contaminants in Wildlife. Lewis Publ., Boca Raton, Florida, pp. 405-425.

Rainbow, P.S. and Phillips, D.J. (1993). Cosmopolitan biomonitors of trace metals. Mar. Pollut. Bull., 26(11): 593-601.

Sadiq, M. (1992). Toxic Metal Chemistry in Marine Environments. Marcel Dekker, New York, 390 pp.

Walsh, A.R. and O’Halloran, J. (1998). Accumulation of chromium by a population of mussels (Mytilus edulis (L.)) exposed to leather tannery effluent. Environ. Toxicol. Chem., 17(7): 1429-1438.

Widdows, J., Nasci, C. and Fossato, V.U. (1997). Effects of pollution on the scope for growth of mussels (Mytilus galloprovincialis) from the Venice Lagoon, Italy. Mar. Environ. Res., 43(1/2): 6979.

Wright, D.A. (1995). Trace metal and major ion interactions in aquatic animals. Mar. Pollut. Bull., 31(1-3): 8-18. 